\title{
The Shipping Act of 1916 and Emergency Fleet Corporation: America Builds, Requisitions, and Seizes a Merchant Fleet Second to None
}

\section{Salvatore R. Mercogliano}

La loi américaine sur le transport maritime, adoptée le 7 septembre 1916, prévoyait la constitution d'une marine marchande américaine, de navires auxiliaires et d'une réserve navale. C'était la première fois que les États-Unis instituaient un contrôle gouvernemental sur leur flotte marchande par l'entremise du bureau des transports maritimes américain. Après l'entrée des États-Unis dans la Première Guerre mondiale, le bureau a créé la Emergency Fleet Corporation pour gérer un programme de construction de navires marchands, réquisitionner des navires en construction et d'autres dans la marine marchande, et saisir les navires allemands accostés dans les ports américains. À la fin de la guerre, la marine marchande et la marine des États-Unis s'apprêtaient, en raison de leur croissance, à faire concurrence à la supériorité navale britannique.

As the United States Congress debated over the issue of war in early April 1917, ninety-four ships of German ownership lay in various American ports, from Boston, Massachusetts to Manila, Philippines. The outbreak of the First World War, three years earlier, had forced these vessels to seek refuge from Allied warships assigned to track and hunt them down. They represented over one-quarter of the German merchant fleet, and among them were nineteen of its prize passenger liners, including the 54,000 gross-ton Vaterland. After the United States adopted a stance of neutrality, President T. Woodrow Wilson had ordered that the rights of the interned ships would be respected and allowed the crews to remain on board. However, with the decision for war on 6 April, a battalion of troops sailed from Governor's Island in New York harbour for the piers of the Norddeutscher Lloyd and Hamburg-American Lines at Hoboken, New Jersey. Other troops, supplemented by US marshals, travelled up the west side of Manhattan to the cargo and passenger piers where other German freighters remained idle. At the appointed time, the troops marched on board, placed the crews under arrest, and hoisted the American flag over their sterns. The seizure of these ships proved only the first of five crucial steps in the successful transportation of two million doughboys in the American

The Northern Mariner/Le marin du nord, XXVI, No. 4 (Oct. 2016), 407-424. 
Expeditionary Force (AEF) to Europe, sustaining the Allied economies, and essential to the success of the Entente powers.

The United States proved ill-prepared to assume this vital maritime role. Aside from the inadequacy of both army and navy maritime transport branches, one of the major reasons for this situation had to do with a clash in personalities between the head of the newly formed US Shipping Board (USSB), William Denman, and the Emergency Fleet Corporation (EFC) - the entity created to construct the wartime fleet of cargo ships - under the man who had overseen the Panama Canal's construction, General George Goethals. They continually bickered over each other's authority, leading to administrative gridlock, until both resigned on 24 July 1917. In their places, Wilson appointed Edward Hurley to head the USSB and eventually Charles Piez to the EFC. The program that each inherited was in chaos, but they managed to overcome the greatest problems and thus allowed General John J. Pershing to get his troops into action by early 1918 , thereby averting possible Allied defeat in France. ${ }^{1}$

Following the initial German unrestricted submarine offensive, and the deaths of 128 Americans on board the British passenger liner Lusitania (7 May 1915), the Wilson administration initiated legislation to create the US Shipping Board - the first government agency assigned the task of regulating and promoting the commercial merchant marine. The president hoped that a renewed American fleet would supplant Britain's in the Western Hemisphere and thereby promote his idealism through "an arm of commerce."' The Shipping Act gave the government the power to build and operate ships during the existing emergency, and up to five years after its conclusion. For the first time in its history, therefore, the American government aimed to challenge the supremacy of the world's largest naval power and engaged directly in the construction and operation of merchant vessels along with a navy second to none, a substantial change in the United States' maritime policy and with long-lasting implications. ${ }^{3}$

Germany's first unrestricted submarine campaign, highlighted the danger to America's status as a neutral and the vulnerability of the nation's trade. Wilson altered his strategy for a national merchant marine by highlighting its importance as a naval auxiliary force. By creating a large commercial fleet, Wilson could direct ships into trade routes vacated by the British, a fact not adopted by American commercial shippers since the domestic market for ships remained so active. These measures, in conjunction with the National Defense and Naval Acts of 1916, represented a distinct effort by Wilson to protect the nation's neutrality, and also to

\footnotetext{
${ }^{1}$ Edward N. Hurley, The Bridge to France (Philadelphia, PA: J. B. Lippincott, 1927), chapter 4.

2 Jeffrey J. Safford, "World War I Maritime Policy and National Security," America's Maritime Legacy: A History of the US Merchant Marine and Shipbuilding Industry Since Colonial Times, (Boulder, CO: Westview Press, 1979),114-116; Jeffrey J. Safford, Wilsonian Maritime Diplomacy: 1913-1921 (New Brunswick, NJ: Rutgers University Press, 1978).

${ }^{3}$ Rene de la Pedraja, A Historical Dictionary of the US Merchant Marine, (Westport, CT: Greenwood Press, 1994), 563-567.
} 
expand its influence beyond the shores. ${ }^{4}$ The initiation of the second period of unrestricted submarine warfare by the Germans on February 1, 1917, served as the catalyst for American entry into the war with the sinking of ten merchant ships and the death of twenty-four Americans and forty others. ${ }^{5}$ Yet, despite the passage of the Naval, National Defense, and Shipping acts, the United States was ill-prepared in April 1917 to transport the American Expeditionary Force (AEF). ${ }^{6}$

It was the passage of the United States Shipping Act of 1916 that initiated this process with its stated purpose:

To establish a United States Shipping Board for the purpose of encouraging, developing, and creating a naval auxiliary and naval reserve and a merchant marine to meet the requirements of the commerce of the United States with its Territories and possessions and with foreign countries; To regulate carriers by water engaged in the foreign and interstate commerce of the United States; and for other purposes.

This law, along with the creation of the USSB, the appointment of the first commissioners on 22 December 1916, and the organization of the EFC on 16 April 1917 under the laws of the District of Columbia with a capital stock of $\$ 50$ million, marked the first instance where the United States instituted government control over the merchant fleet. ${ }^{8}$ William Denman proved unequal to the task as the first head of the USSB, so Wilson turned to Edward Hurley, one of the unsung figures in the Allied victory.

Hurley was born on 31 July 1864 in Illinois. He moved to Chicago in 1881. As a young man, he sold railroad supplies and amassed enough experience and capital to open up his firm, Pneumatic Tool Industry. He proved so adept at the business, that he was able to retire at the age of 38 , but not one to sit idle, he assumed the presidency of a local bank and became interested in Democratic politics. For his support to Woodrow Wilson, the president appointed him to the Federal Trade

\footnotetext{
${ }^{4}$ Naval Appropriations Act for the fiscal year ending June 13, 1917, in US Senate, Navy Yearbook, 64th Cong., 2nd sess., 1916, S. Doc. 555, 480-481. The Naval Act of 1916 authorized the construction of 156 warships including ten battleships, six battle-cruisers, ten cruisers, fifty destroyers, sixty-seven submarines, two gunboats, and eleven auxiliaries

${ }^{5}$ Rodney Carlisle, Sovereignty at Sea: US Merchant Ships and American Entry into World War I (Gainesville, FL: University of Florida Press, 2009), 1-15. The ships lost included SS Housatonic, Lyman M. Law, Algonquin, Vigilancia, City of Memphis, Illinois, Healdton, Aztec, Marguerite, and Missourian.

${ }^{6}$ Hurley, The Bridge to France, Chapter 4.

739 Stat. 728, chapter 451, Sept. 7, 1916.

${ }^{8}$ US Shipping Board, First Annual Report United States Shipping Board (Washington DC: Government Printing Office, 1917), 6-7.
} 
Commission in 1914 and with the US Shipping Board in a period of crisis, he tasked Hurley to take over the reins and sort it out. ${ }^{9}$

With the nations of the world locked in the Great War, Allied vessels diverted to support their war economies, and the loss of over two million tons of shipping, Hurley speedily put the USSB on a wartime footing. He identified five crucial steps to provide the United States with the necessary merchant tonnage. First, the Shipping Board would commandeer all ships, over 2,500 tons, under construction in United States ports. Second, they would requisition all necessary ships flying the American flag. Next, they would repair, refurbish, and recondition the suitable captured German ships for use as troop transports and cargo vessels. Fourth, they would solicit neutral and allied states for additional tonnage, to supplement those ships requisitioned. Finally, the USSB and EFC would initiate a building program for wood, steel, concrete, and composite ships to provide 15 million tons in addition to the 3.5 million tons in operation when the United States declared war. ${ }^{10}$ This effort, aimed to construct 2,851 commercial vessels, along with 156 warships authorized under the Naval Act of 1916, proved second only to the maritime effort by America during the Second World War. ${ }^{11}$

Hurley came to the position with no shipping experience, either as an operator or builder, but he possessed a keen business sense and he knew how to select and delegate authority. To assist him, he appointed Philip A. S. Franklin, the president of the International Mercantile Marine, as the chairman of the Shipping Control Committee, to oversee the movement of all merchant ship traffic and ensure that cargo and ships were coordinated. However, before that could be accomplished, he was also assigned the mission of supporting the deployment of the American Expeditionary Force. Hurley needed to find the passenger ships, freighters, and tankers to support what Secretary of the Navy, Josephus Daniels referred to as, "the biggest transportation job in history." 12

For the majority of Americans, the reality of the war came home in the escalating price of goods and services due to the dramatic increase in freight rates caused by the threat of German cruisers and surface raiders, initially, and then replaced by U-boats. In 1914, to ship cotton from the United States to Europe cost $\$ 0.35$ per one hundred pounds. As dangers mounted to vessels, the increase cost in insurance, and as prices naturally escalated due to the global nature of the conflict, by 1917 , the price had jumped to $\$ 6.10$. Similarly oil, which shipped for $\$ 4$ per ton,

\footnotetext{
9 Ibid., Chapter 1-2.

${ }^{10}$ US Shipping Board, Sixth Annual Report United States Shipping Board (Washington DC: Government Printing Office, 1922), 156.

11 US Shipping Board, Third Annual Report United States Shipping Board (Washington DC: Government Printing Office, 1919), 36.

12 Subcommittee of the Committee on Naval Affairs United States Senate, Naval Investigation (Washington DC: Government Printing Office, 1921), 2114.
} 


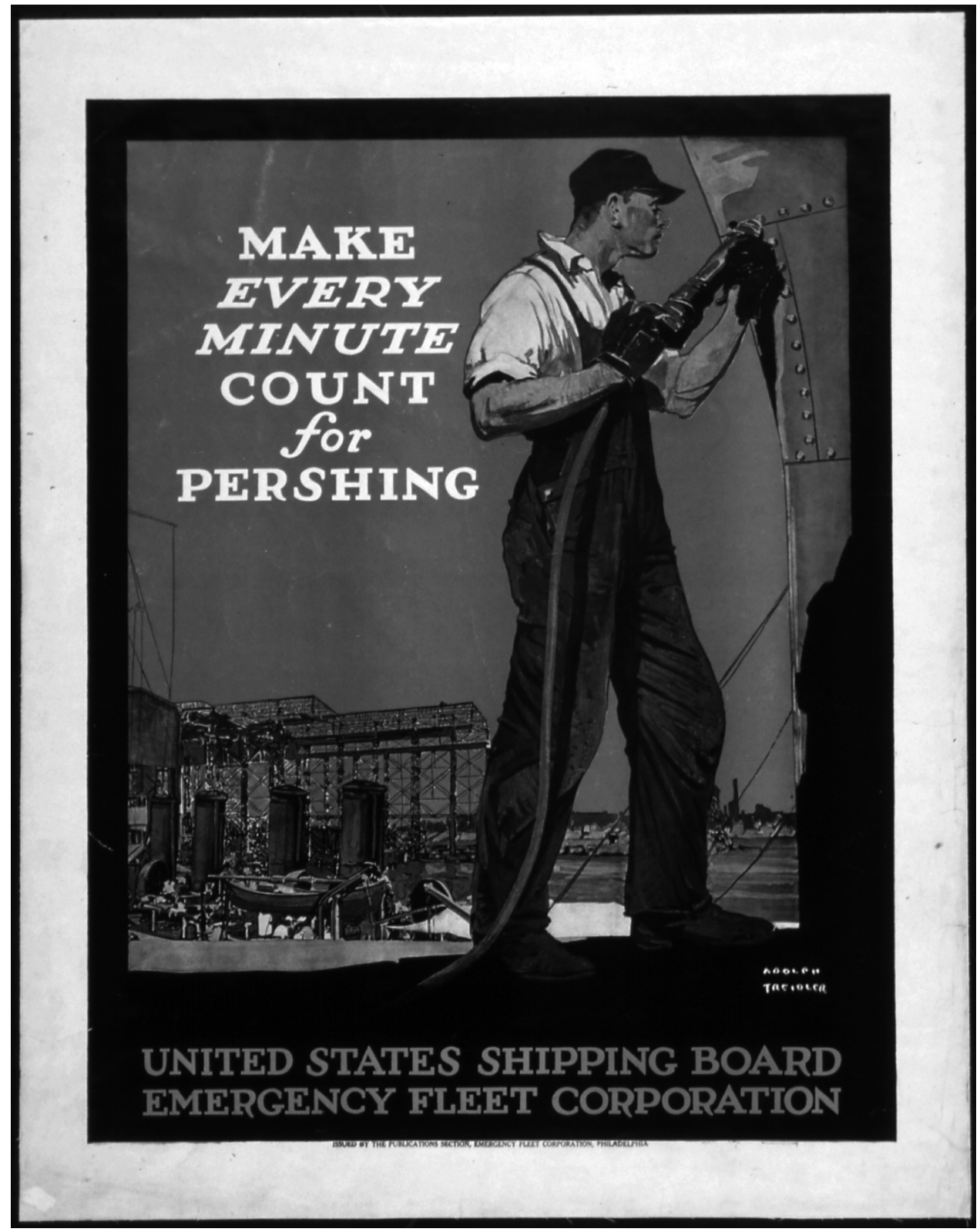

Adolph Treidler (artist). National Archives and Records Administration, RG 4, Records of the U.S. Food Administration, 1917-1920, World War I Posters (https://research.archives.gov/id/512446) 
rose to $\$ 50$. Even more precipitous was the cost to charter vessels for the transportation of any material. The prewar rate of $\$ 1$ a month per deadweight ton spiked at $\$ 20$ a month at the height of the submarine offensive. ${ }^{13}$

As the Americans geared up for war, the passage of the Emergency Shipping Act on 15 June 1917 provided Wilson with virtually unlimited powers to correct deficiencies in the commercial fleet. ${ }^{14}$ The first act in Hurley's plan involved the requisitioning of all 431 merchant ships under construction in the country. Many of these ships were intended for Entente powers - 163 British, 34 French, 4 Italian, 2 Russian, and 1 Japanese - to replace ships destroyed in the German U-boat offensive. $^{15}$ The British were happy to have the Americans on their side, however, they did not want to see them emerge as a rival, either militarily or commercially. In particular, they desperately needed many of these ships to fill in for vessels laying on the bottom of the ocean.

The commandeering of the 61 shipyards - 37 of which specialized in steelhulled vessels with 142 slipways, and 24 wood hull yards with 73 slipways - fell under executive powers conferred by Congress on 11 July 1917. The following month, Mr. Hurley directed then General Manager of the EFC, Rear Admiral Washington Lee Capps, to initiate the order. The government did not assume the management, or even operation of the yards, but prioritized all construction under way, and all future building, for the Emergency Fleet Corporation or the US Navy. Admiral Capps contended that this was a necessary step to insure that the yards had a secure source of goods and materials and to avoid any unnecessary delays, to prioritize the types and classes of vessels being built, and finally, to standardize vessels in order to facilitate and speed construction times. ${ }^{16}$

The acquisition of 431 ships, which equated to over 3 million tons - exceeding the entire seagoing American merchant marine - did not come without issues and protests, particularly from the British. Of immediate concern was the status of SS War Sword, whose completion became a priority. Built by the Union Iron Works of Alameda, California, a subsidiary of Bethlehem Steel, she was a 10,000 deadweightton freighter earmarked for the British Shipping Control office and the Cunard Steamship Company. On 21 August, British Foreign Secretary Arthur Balfour forwarded a letter through the American ambassador in London for American Secretary of State Robert Lansing. In it, Balfour acknowledged American rights to seize ships under construction for foreign powers within the confines of their border, but he addressed the issue of losses due to enemy actions and the desire, "consistent

\footnotetext{
13 First Annual Report United States Shipping Board, 13.

1440 Statute 182, Chapter 29, 15 June 1917.

15 Sixth Annual Report United States Shipping Board, 161. In addition to those ships for the Entente, there were 38 ships under construction for Norway and 4 earmarked for Denmark, along with 185 American vessels.

${ }^{16}$ First Annual Report United States Shipping Board, 10-11; W. C. Mattox, Building the

Emergency Fleet (Cleveland, OH: Penton Publishing, 1920), 33-37.
} 
with the claims of their own national interest to allow the ships now building for us in America to remain in their present ownership." 17

Hurley immediately addressed the request and released SS War Sword, along with twelve other ships, to their British owners since they had been paid for and were at, or near, the point of completion when seized. ${ }^{18}$ This action was meant to assure America's new ally, but in a letter to Minister Balfour, Hurley emphasized the fact that should measures turn dire, the USSB would stop short of nothing to ensure that the nation had an adequate merchant marine: "The American people, in turn, expect us to pay special attention to our soldiers who are to fight our battles thousands of miles from home, and any steps taken whereby these men are not first considered, to my mind, would meet with the general disapproval of the American people."19

With the release of the thirteen vessels to their original orders, the decision to cancel twenty-two of the vessels, and a change in status of twelve others, a total of 384 ships $(2,687,266$ deadweight tons) were earmarked for the EFC. Within the first six months, fifty of them joined the fleet, with another 224 on board by November 1,1918 . With the end of the war, ship construction slowed and the final ship, MS William Penn, a 12,500 ton-freighter entered the fleet on 23 June 1921. Unlike her sister-ships built at the Pennsylvania Shipbuilding Company, of Gloucester, New Jersey, later Pusey \& Jones, she was fitted with a pair of six-cylinder, four-cycle Diesel engine; the first such installation in a commercial ship of the American merchant marine. ${ }^{20}$ This method of propulsion aimed to save over eight thousand dollars for every 10,000 mile of steaming and continued the emphasis on the use of petroleum as fuel, vice coal. ${ }^{21}$

Of the 384 ships acquired from the seizure of the shipyards in the United States, 300 freighters, 53 tankers, 11 refrigerator, 9 transport, 9 colliers, and 2 combined passenger and cargo ships eventually joined the merchant marine. Besides the physical addition to the American sealift assets, the ships under construction in the commercial yards, served as the templates for future Emergency Fleet Corporation design ships. In the Union Iron Works Yard, the builder of SS War Sword, three 11,500 deadweight ton-freighters, under construction for yard account - meaning they were to be sold at a later date, but the onus and cost of construction is on the shipyard - were later contracted by the Emergency Fleet Company and designated as Design 1057 A (SS Liberator and Challenger) and 1057 B (SS Volunteer). ${ }^{22}$ In

\footnotetext{
17 Hurley, Bridge to France, Appendix A.

18 SS War Sword met her fate at the hands of a U-boat, but not until the Second World War. Reflagged to Brazil and named SS Arabutan, she encountered U-155 off Cape Hatteras, North Carolina on 7 March 1942 and was torpedoed while enroute to Trinidad.

19 Hurley, Appendix B.

20 Sixth Annual Report United States Shipping Board, 160-161. The US Navy had experimented with diesel propulsion in USS Maumee, a fuel ship, and in their submarine force with the E-class. 21 "Loaded Sea Trails of the Motorship William Penn," Motorship VI:10 (October 1921), 795-797.

22 N. L. McKellar, "Steel Shipbuilding Under the US Shipping Board, 1917-1921," The Belgian Shiplover 88 (July/August 1962), 395.
} 
other yards, many vessels requisitioned by the government became the templates for other designs, such as the Lake, Point, and West-class freighters.

The second step in the creation of the Emergency Fleet involved the requisition of American merchant ships on the oceans, lakes, and inland waters. On 12 October 1917, Hurley issued the order that allowed for the seizure of all American steel cargo ships and passenger vessels of over 2,500 deadweight tons. This amounted to a pool of 1,614 ships in excess of 3.5 million tons. In particular, the focus was on the 694 steamers and 130 tankers plying the blue water, the 428 sailing vessels in the merchant marine, along with 362 barges were exempt from the requisition order. ${ }^{23}$ With the escalation of freight rates, it was imperative that a control agency coordinate the allocation of tonnage to provide for not only for the military but civilian needs in a balanced manner. ${ }^{24}$ This also alleviated an issue raised with the navy regarding the sailing of merchant ships into the war zone around Europe.

On 7 May 1917, the Navy Department formalized an arrangement when it forbade the use of commercial merchant ships in direct support to the fleet. ${ }^{25}$ The bareboat-chartering of USSB ships by the navy at the end of that year, and the transfer of chartered vessels under the army, culminated in the establishment of the Naval Overseas Transportation Service (NOTS) on 9 January 1918. Envisioned as an emergency service, the NOTS was made responsible for the direct transportation of supplies for the AEF, provisions for naval forces stationed in Europe, and the organization of convoys and armed guards on board merchant vessels. The 558 ships of NOTS, on which the merchant crews donned the uniform of the Naval Auxiliary Reserve (a specific designation for former merchant mariners), transported nearly six million tons of cargo. ${ }^{26}$

By 21 November 1918, the US Shipping Board had requisitioned 450 American merchant ships, including bringing down from the Great Lakes sixty-six vessels of nearly 140,000 tons. Drastic measures had been used. Ships too large to go down the

\footnotetext{
${ }^{23}$ Third Annual Report United States Shipping Board. These numbers are as of April 6, 1917 and do not include ninety-seven seized German and Austrian vessels.

${ }^{24}$ See C. Ernest Fayle, Seaborne Trade, Vol III "The Period of Unrestricted Submarine Warfare," (New York: Longmans, Green \& Co., 1924); J. A. Salter, Allied Shipping Control: An Experiment in International Administration (Oxford: Clarendon Press, 1921).

${ }^{25}$ Lewis P. Clephane, History of the Naval Overseas Transportation Service in World War I (Washington, DC: Naval History Division, 1969), 6. This led to the militarizing of the civilian crews on board the support vessels of the Naval Auxiliary Service (NAS).

${ }^{26}$ Ibid., xvii-xxi; Bureau of Naval Personnel, Military Sea Transportation NAVPERS 10829-A, (Washington DC: Bureau of Naval Personnel, 1954), 48. The navy also promulgated an accompanying priority for manning ships during the war: 1. All troopships and hospital ships were to be manned by the navy. 2. Vessels engaged in the service of the War and Navy Departments to be manned as desired by those departments - which, it was understood, would mean the manning of practically all of such vessels by the navy. 3. Commercial vessels engaged exclusively in trade to ports within the war zone (chiefly food relief vessels) also to be manned by the navy. 4 . Commercial vessels engaged occasionally in such trade, but generally to ports outside the war zone, to be manned as far as possible by merchant seamen. 5 . Commercial vessels engaged exclusively in trade to ports outside the war zone, to be manned by merchant seamen.
} 
Welland Canal had been cut in half, sailed into Lake Ontario, and then reattached in Canadian shipyards before continuing into the Atlantic. ${ }^{27}$

With the acquisition of ships under construction and in service, the third step was to begin the process of transporting and sustaining elements of the American Expeditionary Force in France. In June 1917, the Army Transport Service (ATS) fleet consisted of ten aged troopships and two cargo ships to support army installations between New York and the Panama Canal, from San Francisco to the Philippines, via Hawaii, and among the Philippines. ${ }^{28}$ To move the 1 st Infantry Division to France, the army organized an ad hoc transport fleet, similar to the movement of the VIII Corps to the Philippines in 1898. The ships were "time chartered" (an agreement by which chartering party directs the ship but the operating company provide the crew and all forms of consumables). Sailing in four groups, and heavily escorted, the ships were drawn from commercial sources engaged in the Caribbean or coastal trade. Lessons learned from the Spanish-American War, Philippine-American War, Boxer Rebellion, and Vera Cruz, along with the peacetime operation of the Army Transport Service fleet, provided the necessary experience to identify, convert, and oversee the first fleet of ships. ${ }^{29} \mathrm{With}$ an initial capability to transport 15,000 troops and nearly 50,000 tons of equipment a month, the difficulty in transporting over two million troops and six million tons of cargo seemed a daunting achievement in less than two years. ${ }^{30}$

The problems encountered with this first shipment, along with the proposed scope of the sealift effort, convinced the army that it did not want to divert any of its personnel from the primary goal of fielding and manning the AEF. To man the transports and supply ships of the ATS, the army agreed in July 1917, to place them under navy operational control. ${ }^{31}$ To oversee this task, Secretary of the Navy Josephus Daniels appointed Rear Admiral Albert Gleaves to command the Cruiser

\footnotetext{
27 US Shipping Board, Second Annual Report United States Shipping Board (Washington DC: Government Printing Office, 1918), 55.

${ }^{28}$ Report of the Quartermaster General (Washington DC: Government Printing Office, 1917), 55. These ships include the US Army Transports (USAT) Crook, Logan, Sheridan, Sherman, Thomas, and Dix operating in the Pacific; Buford, Kilpatrick, and McClellan in the Atlantic, and Liscum, Merritt, and Warren in and around the Philippines.

${ }^{29}$ Henry G. Sharpe, The Quartermaster Corps in the Year 1917 in the World War (New York: The Century Co., 1921), 359-360. The four convoys consisted of: Convoy I: Saratoga and Havana (NY \& Cuba Mail Steamship), Tenadores and Pastores (United Fruit Co.); Convoy II: Momus and Antille (Southern Pacific Co.), and Lenape (Clyde Steamship Co.); Convoy III: Mallory and San Jacinto (Mallory Steamship Co.), and Finland (International Mercantile Marine); Convoy IV: USS Hancock ( US Navy transport), Montanan (American Steamship Co.), Dakotan (American \& Hawaiian Steamship Co.), El Occidente (Southern Pacific Co.), and Edward Luckenbach (Luckenbach Steamship Co.).

${ }^{30}$ War Department, Report of the Chief of Transportation Service, Fiscal Year 1919 (Washington DC: Government Printing Office, 1919), 14; Benedict Crowell and Robert Forrest Wilson, The Road To France: The Transportation of Troops and Military Supplies, 1917-1918, Vol. II (New Haven: Yale University Press, 1921), 313-322.

31 Military Sea Transportation, 47.
} 
and Transport Force (CTF). ${ }^{32}$ Retaining five of the original seven transports from the summer of 1917, the army and navy arranged for the transfer of USSB ships, requisitioned ones from the US merchant marine, and the repair and conversion of nineteen German, and one Austrian interned passenger ship. The Germans and Austrians aimed to deny the ships to the Americans by sabotaging their machinery, including disabling pumps, dry firing boilers, and destroying auxiliary machinery. There was only one case of the Germans scuttling a vessel, SMS Cormoran in Guam, but all the others experienced some level of damage, with the hope that when the war ended, they would be returned to Germany and placed back into service. ${ }^{33}$

Almost immediately after war was declared, Congress appropriated funds to repair and formally incorporate the vessels into the American fleet, initially under the USSB, then the army, and finally, the navy. Besides the passenger ships, fiftynine German and six Austrian freighters added nearly 400,000 tons of cargo space to the merchant fleet operated by the USSB. ${ }^{34}$ Spending over $\$ 11$ million on repairs, the result materialized in early June 1917, as the first of the twenty passenger ships SS Prinz Eitel Freidrich, renamed De Kalb - entered service with the navy. ${ }^{35}$

By the time of the armistice, forty-one converted passenger ships were detailed to the CTF, increasing their capacity to move troops monthly by a factor of ten, while five others had either been lost or transferred. ${ }^{36}$ All told, 2,079,880 members of the AEF travelled to France, of which 46 percent sailed on American-flagged vessels, and 557,788 were carried on board the former liners of the Kaiser. ${ }^{37}$

To inflame the British and the Germans further, Hurley and the shipping board took drastic measures to acquire cargo ships to sustain the AEF. The commandeering of new construction, active American ships, and use of interned ones failed to provide the necessary tonnage. Shipbuilding would eventually alleviate the problem but the situation developed that the American troops arrived in France faster than their supplies. To overcome this problem the USSB adopted step four of Hurley's plan and actively chartered ships from many nations, including

\footnotetext{
32 Josephus Daniels, Our Navy at War, (New York: George H. Doran Company, 1922), 71; Albert Gleaves, A History of the Transport Service (New York: George H. Doran Company, 1921).

${ }_{33}$ See Herbert T. Ward, Flight of the Cormoran (New York: Vantage Press, 1970).

34 Second Annual Report United States Shipping Board, 44-45, 55.

35 Hurley, Bridge to France, Chapter V: Benedict Crowell and Robert Forrest Wilson, 331-346,

${ }^{36}$ Crowell and Wilson, 322, 564-567; Gleaves, 240. The ships transferred included SS Saratoga and Havana, which became the US Navy hospital ships Mercy and Comfort. The Dutch chartered ship SS Koningen der Nederlanden was removed from the CTF and transferred to the Naval Overseas Transport Service as a freighter, subsequently sunk. The other two troopships were lost on return voyages; SS Covington and SS President Lincoln.

37 The twenty interned German and Austrian passenger ships were Leviathan (Vaterland), Agamemnon (Kaiser Wilhelm II), Madawaska (Koenig Wilhelm II), President Lincoln, President Grant, Mercury (Barbarossa), Aeolus (Grosser Kurfurst), Powhatan (Hamburg), Huron (Friedrich der Grosse), Pocahontas (Princess Irene), George Washington, Martha Washington, De Kalb (Prinz Eitel Friderich), America (Amerika), Antigone (Neckar), Convington (Cincinnati), Mount Vernon(Kronprinzessin Cecile), Susquehanna (Rhein), Von Steuben (Kronprinz Wilhelm), and Princess Matoika (Princess Alice).
} 
Sweden, Norway, Denmark, and Japan, while also seeking the return of interned German and Austrian ships in South American countries. ${ }^{38}$

Two American agencies, the US Shipping Board and the War Trade Board, coordinated the charter agreements between the US and the Scandinavian countries for their vessels. The Scandinavian countries agreed to make available to the United States over a million-and-a-half tons of ships, under certain provisions. For example, the Swedish required half of the 200,000 tons made available to the US for the transport of iron ore from Sweden, to protect their domestic industry. For the Danes, a similar requirement was made, but this one was geared toward the delivery of food supplies to Denmark and for Belgian relief. ${ }^{39}$

Japan, an ally during the First World War, agreed to release twenty-three vessels while negotiating for the construction of fifteen ships for the Emergency Fleet Corporation. This was later expanded to provide for half of all new tonnage constructed in Japan until August 1919. In exchange for these ships, the US agreed to provide one ton of steel for every two tons of ships. These agreements eventually amounted to over forty-five ships of 375,000 tons. ${ }^{40}$

One of the most unusual agreements called for the Dutch to provide 460,000 deadweight tons of shipping. However, when they had produced only 300,000 tons, the Dutch reneged on the remaining tonnage due to fears of German reprisals. Hurley, desperate for the hulls, went to President Wilson to implement the right of angary. This concept, an ancient maritime practice whereby a nation at war could seize another nation's ship, was extreme to say the least, but Wilson signed the order under the executive authority given to him on 15 June 1917. On 20 March 1918, US troops and federal officers disguised as longshoremen and stevedores moved into position alongside eighty-seven Dutch ships in American ports. At the appointed time, they rushed up the gangways and seized control of 533,746 deadweight tons of neutral shipping. The 2,934 Dutch crewmen were interned in the United States and the government agreed to compensate the owners for the $\$ 2$ million in cargo on board the ships and allow the crews to be repatriated. The Dutch sailors were the "guests" of the Americans until returned to their home country on board the liner New Amsterdam. It was not until 3 July 1918 that all but three sailors, detained due to illness, were repatriated. ${ }^{41}$

The requisition of ships under construction, along with those sailing under the American, neutral, and enemy flags, provided the short term solution to the mounting issue of the United States fielding, not just the AEF, but sustaining the Allies into the immediate future, possibly until victory could be achieved in 1919, 1920, or later. Very few leaders envisioned Allied success in the fall of 1918. The long-term solution was a program that built upon the existing American shipyard infrastructure, created new yards to construct ships that were largely built offsite and

\footnotetext{
38 Second Annual Report United States Shipping Board, 46-54; Hurley, Bridge to France, Chapters XII and XIII.

39 Second Annual Report United States Shipping Board 52-53.

40 Ibid.

41 Ibid. 47-52; Hurley, Bridge to France, Chapter XIII.
} 
then assembled along the shore, and the utilization of technologies, some new, and some old, to construct 2,863 ships capable of transporting fifteen-and-a-half million deadweight tons of cargo. This fifth and final step would prove to be the boldest and most daunting step taken by Edward Hurley, the US Shipping Board, and the Emergency Fleet Corporation.

To build a navy and merchant marine second to none, required shipyards, but the naval emergency, in particular the need for convoy escort vessels, preoccupied the naval shipyards, and many of the key commercial firms, such as Fore River, Bath Iron, Union Iron, and Newport News, along with the 431 merchant ships already under construction. To produce the requisite tonnage required an expansion of existing yards, the construction of new ones, and development of four large prefabrication yards for steel vessels, five such facilities for concrete ships, and a renewed interest in wood construction.

Before Edward Hurley assumed the chairmanship of the US Shipping Board, William Denman promulgated the first of 532 contracts on 29 April 1917. This agreement, with the Merrill-Stevens Shipbuilding Company of Slidell, Louisiana was for eight $\mathrm{McClelland-type,} \mathrm{three-island,} \mathrm{3,500} \mathrm{deadweight-ton} \mathrm{freighters.} \mathrm{These}$ ships were fairly typical freighters for the time. They were 268 feet in length, and had a 46-foot beam, and a 26-feet draught. They could haul nearly 150,000 cubic feet of cargo in their twin holds with a single tween deck which was serviced by eight five-ton booms. A pair of coal-fed water tube boilers, and a single tripleexpansion 1,400 horsepower engine, produced a speed of ten knots. Where they stood out was in the selection of construction material.

While the McClellands featured steel frames and keels, they were fitted with wooden hulls. It was envisioned that this composite construction, would free up resources for higher-priority naval combatants and other items. Yet, the mash up of materials proved more difficult to work with and the first ship, SS Red Cloud did not enter service until August 1918. The emphasis for the construction of composite, and subsequently all-wooden ships was the brainchild of William Denman. This did not sit well with the head of the Emergency Fleet Corporation, George Goethals, and while Edward Hurley did not believe that this was the issue that led to their falling out, he did note that while Denman urged the program, he was "strongly opposed" by Goethals. ${ }^{42}$ Nevertheless, when Hurley assumed the reins of the USSB and EFC, he continued the program, intending the ships to be used outside of the war zone. From an original program of 1,017 vessels, including 640 freighters, one tanker, 161 tugs, 10 sailing vessels, and 205 barges, USSB and commercial yards completed only 589 for $1,885,250$ deadweight tons. ${ }^{43}$

The allure of wooden ships stemmed from the availability of labour, the ability to train personnel in wood-working vice steel, and the nearly unlimited supply of lumber and material in certain regions of the United States, particularly the southeast

\footnotetext{
${ }^{42}$ Edward Hurley, The New Merchant Marine (New York: The Century Comp., 1920), 28.

43 US Shipping Board, Fourth Annual Report United States Shipping Board (Washington DC, 1920), 98-99.
} 
and northwest areas. Finally, the tradition of many small shipbuilders was in this field, and it was hoped the process of scaling would not impact the end result. Design 1001 proved the most common type of wooden cargo ship built by the EFC. Known as the Ferris-type for its designer, noted naval architect Theodore Ferris, at 281 feet and 10 inches and with a cargo capacity of 3,588 deadweight tons, she was a four-hold, three-island freighter. With a speed of ten knots, they were akin to the Liberty ships of the Second World War. However, the need for ships led to some unique build arrangements. Since the EFC contracted with many new shipyards, and several old ones, who had specialized in the design and construction of wooden vessels, but under sail power, many of the ships completed were finished without their main engines installed. Instead, once their hulls were completed, they would receive them and other machinery at another facility. After Germany collapsed, many of the Ferris and other wooden freighters, were towed to holding anchorages, in particular a massive one at Claremont, Virginia for 226 of these powerless freighters. ${ }^{44}$ The Western Marine \& Salvage Company purchased most of these powerless hulls and relocated them to Mallows Bay, Maryland. Once there, they were stripped of all material and then burned. ${ }^{45}$

On the West Coast of the United States, where ships had to make long voyages across the Pacific, shipbuilders focussed on larger hulls with associated increased cargo space, and range. As part of the initial requisition orders, freighters under construction in Seattle, Washington, at the Ames Shipbuilding and Drydock, J. F. Duthie \& Company, Skinner \& Eddy, and those in Portland, Oregon at Columbia River Shipbuilding and Willamette Iron \& Steel Works, Portland were all the basis for what became the EFC Design 1013.

Referred to as the Robert Dollar-type, these ships were 8,800 deadweight tons, or nearly three times the capacity of the wooden Ferris-class EFC 1001 design. At 410 feet and 6 inches, with a beam of of 53 feet and a draught of 30 feet, they were fitted with either triple-expansion or steam turbine engines and many utilized oil for fuel. A total of 111 were produced from West Coast yards, and all readily identifiable by the "West" prefix in their names. Their distinct five-hole arrangement, with two forward of the bridge, one smaller hold between the bridge and the funnel, and then two aft, along with a good internal arrangement, allowed for the carriage of variety of goods and commodities. They proved so successful, that the EFC authorized subsequent ships, such as the 55 freighters of EFC 1019 and the twelve of EFC $1080 .{ }^{46}$ While a tremendous asset to the US, allied nations, in particular the British and Japanese, viewed these cargo ships with suspicion in their future use.

\footnotetext{
${ }^{44}$ N. L. McKellar, "American Wooden Shipbuilding in World War One," The Belgian Shiplover (September/October 1959), 319-320.

${ }^{45}$ CNN, "Mallows Bay: The 'ghost fleet' graveyard where nature has risen from the dead," 8 January 2016 and "Mallows Bay - Potomac River," santuries.noaa.gov/mallows-bay/ (Accessed April 10, 2016).

${ }^{46}$ N. L. McKellar, "Steel Shipbuilding Under the US Shipping Board, 1917-1921," The Beglian Shiplover 89 (September/October 1962), 475a.
} 
Another area where the EFC concentrated on was the building of steel freighters on the Great Lakes, America's fourth coast. Taking advantage of the large shipbuilding industry scattered around the largest fresh water sea in the world, the EFC contracted for a series of seven designs that together, were commonly referred to as the Lakers; again for their prefix.

The tonnage of the Lakers varied, ranging from 3,350 to 4,220 tons, but they all shared one common characteristic. At 261 feet in length, they could navigate the Welland Canal between Lakes Ontario and Erie, and therefore access the St. Lawrence River and the Atlantic Ocean. They were built all along the southern shores of the Great Lakes, at American Ship Building Company facilities in Buffalo, NY; Chicago, Illinois; Cleveland, Ohio; Detroit, Michigan; Lorrain, Ohio; Superior, Wisconsin, and Toledo, Ohio; along with other companies, such as Globe Shipbuilding of Superior, Great Lakes Engineering Works in Ashtabula, Ohio and Ecorse, Michigan; Manitowoc Shipbuilding of Wisconsin, McDougall-Duluth Shipbuilding in Minnesota, and Saginaw Shipbuilding located along the shores of Michigan. Of the 448 planned Lakers, 333 were completed to seven different designs (EFC 1020, 1042, 1044, 1060, 1079, 1093, and 1099). ${ }^{47}$

Many of the ships found service with the navy in NOTS and were sent to Europe and used for the army in their cross-channel operation between England and France as shuttle ships. Too small for trans-oceanic service after the war, many operated as coastal freighters, but with the economic slowdown in the late 1920s, the USSB scrapped excess hulls as uneconomical or sold them to foreign concerns. Nevertheless, they represented a major component of the USSB shipbuilding effort.

The last major area where ship construction took place was along the East Coast. This area was the location of the majority of the major shipyards in the United States. ${ }^{48}$ It was in many of these yards, that the USSB requisitioned ships under construction, or the US Navy contracted for warships. Yet, these yards were also the location of those possessing the skills and talents necessary to not only build ships, but share that knowledge with the scores of new workers needed. The USSB and EFC contracted with the yards to supplement their construction with additional hulls. The Bethlehem Steel Shipbuilding Company, with yards in Baltimore and Sparrows Point Maryland; Elizabethport, New Jersey; Quincy, Massachusetts; Staten Island, New York; and Wilmington, Delaware was a prime example. Once again, existing ships were continued by the USSB and EFC Designs 1031, 1094, 1016, and 1046 reflect this.

With shipyards at capacity, it became necessary for the USSB to adopt prefabrication. William Thiesen, in Industrializing American Shipbuilding, identified this method of construction as a "new American style of shipbuilding"

\footnotetext{
47 N. L. McKellar, "Steel Shipbuilding Under the US Shipping Board, 1917-1921," The Beglian Shiplover 87 (May/June 1962), 272; and Tim Colton, General Cargo Ships Built in Great Lakes Shipyards (http://shipbuildinghistory.com/history/merchantships/wwi/lakes.htm, 6 August 2008).

48 Third Annual Report United States Shipping Board, 150-154. Shipyards along the Gulf of Mexico coast accounted for EFC Designs 1027, 1037, 1038, and 1025, a total of thirty-six freighters.
} 
prior to the First World War. ${ }^{49}$ Specifically, it had been adopted by the Submarine Boat Corporation, a subsidiary of the Electric Boat Company, for the construction of 550 Royal Navy wooden submarine chasers. The parts were built in a facility at Bayonne, New Jersey, and then shipped to assembly sites in Montreal and Quebec. ${ }^{50}$ Naval architects formulated ships with simple lines, flat decks, few curves, and utilized bridge-grade steel, in lieu of higher tensile strength maritime steel. ${ }^{51}$

Four contractors were awarded fee-based agreements to establish the American International Shipbuilding yard at Hog Island, Pennsylvania; the Merchant Shipbuilding Corporation in Bristol, Pennsylvania; the Submarine Boat Corporation of Newark, New Jersey; and the Carolina Shipbuilding Company along the shores of the Cape Fear River in North Carolina. Each of these yards did not build the vessels in the traditional sense, but assembled the pieces, which were manufactured off-site and capable of being transported by rail. This method of ship construction, which is the standard in modern assembly facilities, had never been attempted on such a scale. ${ }^{52}$

Total contracts for the ships were as follow: $:^{53}$

American International Shipbuilding Corporation

- 50 shipways

- 110 EFC 1022 Cargo ships (7,500 deadweight tons)

- 70 EFC 1024 Combination cargo and troops ships (8,000 deadweight tons)

Merchant Shipbuilding Corporation

- 12 shipways

- 60 EFC 1025 Cargo ships (9,000 deadweight tons)

Submarine Boat Corporation

- 28 shipways

- 150 EFC 1023 Cargo ships (5,000 deadweight tons)

Carolina Shipbuilding Corporation

- 4 shipways

- 12 EFC 1037 Cargo ships (9,600 deadweight tons)

They represented 402 ships of 2,790,200 tons, at an estimated cost of half a billion dollars, a fleet greater than the entire pre-war American merchant marine.

The end of the war in November 1918 meant some of the ships were not built. American International Shipbuilding did not complete its first ship, SS Quistconck,

\footnotetext{
49 William H. Thiesen, Industrializing American Shipbuilding: The Transformation of Ship Design and Construction, 1820-1920 (Gainesville, FL: University of Florida Press, 2006), 169-212.

${ }^{50}$ Mark H. Goldberg, The Shipping Board's “Agency Ships, ” Part I - “The Sub Boats,” (King's Point: The American Merchant Marine Museum, 1994), 5-8.

51 Second Annual Report United States Shipping Board, 129.

${ }^{52}$ Mark H. Goldberg, The "Hog Islanders": The Story of 122 American Ships (King's Point, NY: American Merchant Marine Museum, 1991), and The Shipping Board's “Agency Ships, ” Part I The "Sub Boats."

${ }^{53}$ Second Annual Report United States Shipping Board, 129: N. L. McKellar, "Steel Shipbuilding Under the US Shipping Board, 1917-1921," The Beglian Shiplover 87 (May/June 1962), 273.
} 
until December 3, 1918. Only 110 freighters and a dozen transports were delivered before the yard closed in 1921. Of the 402 ships, 312 were completed for the USSB, and another thirty-four in the assembly yards for private companies. ${ }^{54}$

The First World War seemingly vindicated the need for a strong national merchant marine, in conjunction with a navy, if the United States desired to be a true maritime power. It also highlighted the overwhelming fact that one could not be constructed overnight. America had to build, requisition, and seize a merchant fleet second to none, except for the British. The reliance on the Allies for transporting the bulk of the AEF and a large portion of its supplies reduced the influence that the Americans had upon peace negotiations at Versailles, and both the commercial industry and the military sought to prevent a recurrence.

The war's end did not immediately deter America from continuing construction of a new merchant fleet. By 1 December 1918, the USSB had delivered only 274 ships, and this situation caused a serious dilemma for the American government; should the remaining vessels be completed and what should be done with those already in operation? $?^{55}$

When Wilson travelled to Paris for the peace conference he used these ships, and the extensive shipbuilding facilities developed during the war, for leverage in his negotiations with the Allies. The British greatly feared a strong American maritime presence and all the Allies competed for control of the vast German merchant fleet. One of the greatest conflicts emerged over the disposition of the super-liner Imperator and eight other passenger ships, desired by the United States to aid in the repatriation of the AEF, and a fleet of nine Standard Oil tankers previously under the German flag. An eventual agreement to return the tankers to Standard Oil, and to award the Imperator to Britain, after its temporary use by the Americans, defused the situation but the Shipping Board continued to build ships until $1922 .{ }^{56}$

To formalize America's position, particularly, with the change of presidential administrations, the Merchant Marine Act of 1920, sponsored by Senator Wesley Jones (R-WA) and more commonly referred to as the Jones Act, reinstated cabotage, outlawing foreign-built and flagged vessels from participating in the American coastal trade. This had been a major source of shipping at the beginning of the First World War, but restrictions had been loosened during the conflict. The Jones Act gave the shipping board the authority to sell off its excess tonnage and to use some of the war-built fleet to establish and maintain vital trade routes. These ships could either be chartered to commercial companies or operated by the government in order to accomplish this aim, such as the Panama Canal Company or United States Lines. However, the board neglected to formulate a long-range plan. Instead of allocating ships to several firms on key routes, it flooded the market with vessels, and in many cases placed domestic firms in competition with each other. This situation allowed

\footnotetext{
${ }^{54}$ Second Annual Report United States Shipping Board, 129-132.

55 Sixth Annual Report United States Shipping Board, 264-265.

56 Jeffrey J. Safford, Wilsonian Maritime Diplomacy, 1913-1921, 199-219.
} 
foreign companies to swoop in and undercut the American companies. ${ }^{57}$ Rene de la Pedraja acidly commented on this scheme and its originator, the new head of the Shipping Board, ex-chief of naval operations Admiral William S. Benson, he "had built the whole merchant marine plan on the shifting sands of the new managing operators, most of whom were in the business only as long as they could make quick and easy profits." 58

The Jones Act failed primarily because of the collapse of the post-war shipping boom, and the economic recession of the early 1920s, particularly due to failing grain prices. The reemergence of full-scale British competition, along with the downward spiral of freight rates and the higher costs of operating American ships, resulted in a renewed shift of international trade toward foreign flags. These higher costs were due to several reasons. The first was increased salaries to American mariners due to high labour demand generated by the wartime decline of foreignflagged shipping in exporting US goods and the simultaneous growth of the American merchant fleet. An able bodied seaman who earned \$35 a month on the eve of the war was receiving $\$ 85$ by $1919 .{ }^{59}$ This rise in salary represented a tremendous burden to the shipper. Attempts to cut wages resulted in strikes. A large surplus of seafarers, along with declining union membership, forced an eventual reduction in crew salaries, although not before British and other European firms had reclaimed many of their previous trade routes. Additionally, many foreign shipping lines established conferences, whereby competing companies agreed to offer set rates on a specific freight line. This price-fixing eliminated rate wars, ensured steady income, and allowed them, in many cases, to underbid American companies, which were barred by law from participating in such arrangements. Once foreign firms monopolized particular routes they could and did increase rates. ${ }^{60}$ With a "Return to Normalcy" under the Harding administration, these factors all served to undermine Wilson's efforts and the American commercial and sealift fleet began to decline, once again.

A second factor contributing to the post-war decline had to do with the ships built by the USSB during the war. Unlike the next war, in which standardization would be the rule, the government allowed each shipyard to formulate its own ship design, to be specific, ninety-nine different plans. In many cases, the yards simply utilized existing plans with only slight modifications. In the case of Hog Island, which was a new yard, excellent vessels were built from scratch, but a large majority of the ships constructed elsewhere were obsolete and of uncompetitive designs. Of the 3,282 ships composing the Emergency Fleet Corporation program, 1,017 were

\footnotetext{
57 H. David Bess and Martin T. Farris, US Maritime Policy: History and Prospects (New York: Praeger, 1981), 44-45; Pedraja, A Historical Dictionary of the US Merchant Marine, 286-287.

${ }^{58}$ Rene de la Pedraja, The Rise \& Decline of US Merchant Shipping in the Twentieth Century, (New York: Twayne Publishing, 1991), 62.

${ }_{59}$ Benjamin W. Labaree, William M. Fowler Jr., Edward W. Sloan, John B. Hattendorf, Jeffrey J. Safford, and Andrew W. German, America and the Sea: A Maritime History (Mystic, CT: Mystic Seaport, 1998), 543-545.

${ }^{60}$ Ibid., 525; Pedraja, A Historical Dictionary of the US Merchant Marine, 144-145.
} 
built from wood, 50 of wood and steel composite, and 43 from concrete, leaving 2,172 , including 431 requisitioned from private shipyards, built wholly of steel. ${ }^{61}$

Yet, the five-step program initiated by Hurley served as the template for American success in the Second World War. On 12 March 1921, the keel of the final USSB vessel was laid at the Bethlehem Steel Shipyard in Sparrow's Point, Maryland. Launched as SS Nutmeg State - EFC Hull Number 2507 - she was one of the sixteen 535-class. While the Emergency Fleet Corporation built many different types of freighters, it only completed thirty-eight passenger vessels. Renamed SS Western World and operated by the Munson Line under a lease arrangement until bought in 1925, the ship continued in operation until the line declared bankruptcy and was seized by the replacement for the USSB, the US Maritime Commission. In 1939, with another war looming on the horizon and as the United States ramped up a new shipbuilding program, that would double the effort by Edward Hurley and the USSB, Western World was taken over by the military and designated as USAT (Army Transport) Leonard Wood. Two years later, she was transferred to the Navy, as part of an operating agreement similar to that of the First World War, and designated USS Leonard Wood. Classified initially as a transport, and then an attack transport, and crewed by the US Coast Guard, she participated in operations from North Africa, throughout the Mediterranean and across the Pacific, earning eight battle stars in the process. ${ }^{62}$

On 13 May 1947, USS Leonard Wood, ex-ATS Leonard Wood, ex-Western World, ex-Nutmeg State, entered the National Defense Reserve Fleet anchorage in Astoria, Oregon. She only resided there until 20 January when the Consolidated Builders took possession of the ship and towed her for scrap. Built too late for service in the First World War, in the inter-war years she served as a passenger liner for many years until the merchant marine for which she was built, once again suffered the doldrums of neglect, government infighting, and shifting economic factors. While she failed to deliver doughboys to France, in the years following that conflict and in the maelstrom of the Second World War, she and her sister ships found their calling. They formed the template for the massive shipbuilding program initiated under the Merchant Marine Act of 1936 and the creation of the US Maritime Commission. The second iteration of the Shipping Act of 1916 two decades later provided the bridge of ships between the Arsenal of Democracy and the battlefields of Europe, Africa and Asia.

\footnotetext{
${ }^{61}$ Hurley, The Bridge to France, Chapter VII; W. C. Mattox, Building the Emergency Fleet.

${ }^{62}$ US Navy, Navy and Marine Corps Awards Manual, NAVPERS 15,790 (Washington DC: Bureau of Naval Personnel, Rev 1953),

https://www.ibiblio.org/hyperwar/USN/ref/Awards/Awards-IV-16.html.
} 